\title{
Assessment of feasibility of using the existing electric power infrastructure for charging electric and hybrid vehicles
}

\author{
Vyacheslav Rakov ${ }^{1, *}$, Oleg Pikalev ${ }^{1}$, Timur Akhmetov ${ }^{2}$, Tamara Budavina ${ }^{1}$ and Peter Smirnov ${ }^{1}$ \\ ${ }^{1}$ Vologda State University, Department of automobiles and automobile industry, 160000 Lenin st., 15, Russia \\ ${ }^{2}$ Kazan State Power Engineering University, Kazan, Russia
}

\begin{abstract}
Many countries around the world are considering the possibility of a complete transition to electric cars. This raises questions about the capabilities of the existing infrastructure for electricity generation. This paper presents calculations on the example of the Russian power system. It is conventionally accepted that all cars with petrol engine will be run on electricity. To understand how much electricity consumption will change, a calculation technique has been proposed. As initial data, statistics on the production of electricity, petrol and diesel fuel over the past 20 years was used. As methodological approaches, a generalization and calculation were carried out, on the basis of which a theoretical experiment was conducted. The authors concluded that the increase in electricity consumption will be only $5 \%$, which will not create an excessive load on the existing energy infrastructure.
\end{abstract}

\section{Introduction}

In many countries of the world, the possibility of converting a significant part of vehicles to run on electricity is being considered. It is planned to charge them using the capabilities of the existing power system. 2019 global annual growth in sales of electric vehicles worldwide exceeded 1 million units per year, while the annual growth rate over the past 5 years is about $30 \%$. The governments of many countries and car manufacturers are gradually displacing cars with petrol and diesel engine and develop production of electric cars.

This paper considers the example of power system of Russia. In Russia, the number of electric vehicles already in use is insignificant: only about 6 thousand. However, government development programs contribute to their popularity. The largest number of electric buses among all European capitals of the world is in Moscow. The transport strategy of Russia for the period until 2030 involves increasing the environmental safety of transport, including by expanding the use of electric cars, which are environmentally-friendly vehicles. For example, since 2020, in Russia, customs duties on the import of electric vehicles are reset to zero, which clearly indicates a state stimulation of demand for them. The infrastructure of electric vehicle charging station network will also expand significantly in the coming years [1-2]. Along with an increase in the number of electric cars, the number of electric charging stations is also growing. According to the official website https://electromobili.ru, from 2018 to 2020 , their number in Russia has grown 3 times and today is 161 pcs.
However, it should be noted that when planning the development of electric car fleet, it is necessary to assess the capabilities of the existing system for production and distribution of electricity. The influence of electric transport on power systems is considered in papers of D.Yu. Tsypulev [3-4]. Studies are also being conducted to optimize the placement of charging stations, taking into account the present infrastructure and the routes of electric vehicles [5]. However, after analyzing many scientific works, the authors did not find a sufficiently broad study of the considered issues. The present paper analyzes the possibility of adapting the electricity infrastructure to power a significant number of charging stations using the example of Russia.

For the period until 2030 the development dynamics of the power system of Russia implies a large-scale decrease in specific energy consumption in the economy and energy (by 2.1-2.3 times) with a significant increase (by 1.4-1.6 times) in the number of consumers and growth in electricity exports (by 1.1-1.2 times). Currently, the growth in energy consumption is not increasing, and even may slow down after 2020.

\section{Materials and methods}

Statistical information on the production of electricity, petrol and diesel fuel in Russia was used as the initial data for the study.

A characteristic of electricity production by years over the past 20 years was compiled based on the open source data of the Ministry of Energy of the Russian Federation, Figure 1. The plot shows that the annual electricity production in Russia is about 1,050 billion $\mathrm{kW} \cdot \mathrm{h}$ and has stabilized over the past year.

* Corresponding author: vyacheslav.rakov@ mail.ru 


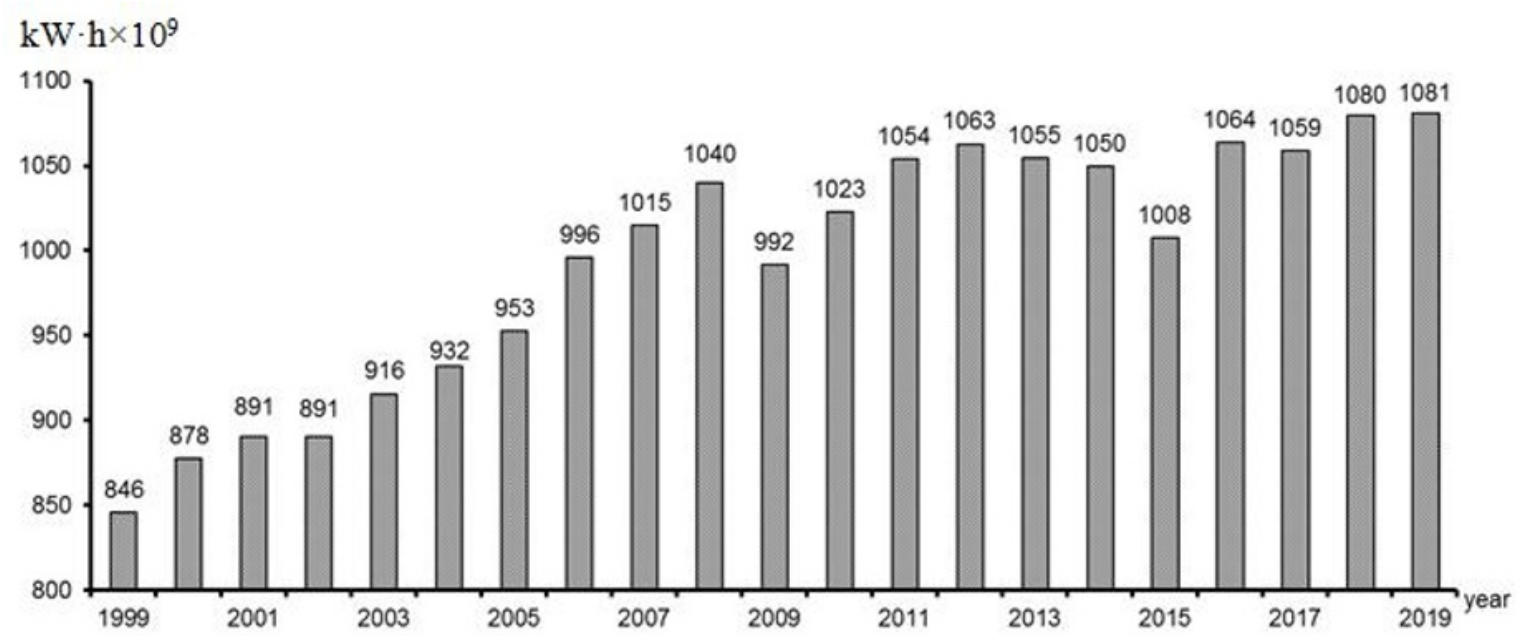

Fig. 1. The dynamics of electricity production over the past 20 years in Russia.

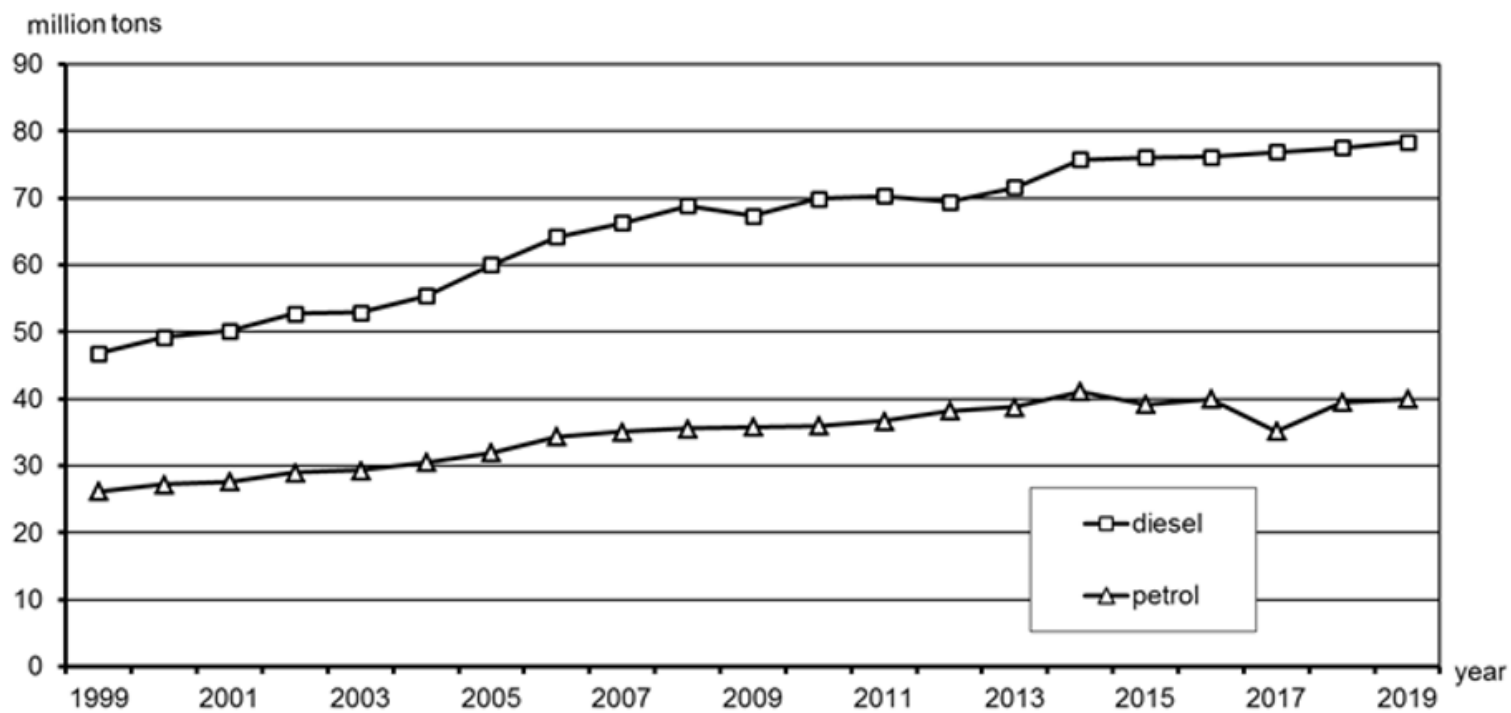

Fig. 2. The dynamics of gasoline and diesel fuel production in Russia over the past 20 years.

The amount of produced petrol and diesel fuel is determined based on data of the Federal State Statistics Service. Figure 2 shows, that Russia annually consumes about 80 million tons of diesel fuel, and 30 million tons of petrol. The increase in fuel consumption is negligible.

As a rule petrol is used as a fuel for cars. The amount of diesel fuel consumed by cars is very small, therefore, it is not taken into account in calculations.

We can compare the volumes of produced electricity and hydrocarbon fuel by reducing them to uniform terms [6]. For this, $\mathrm{kW}$ per hour and the energy of hydrocarbon combustion are reduced to MJ using the well-known relationship (1):

$$
1 \mathrm{~kW} \cdot \mathrm{h}=3.6 \mathrm{MJ}
$$

For initial data on the produced electricity for the year 2010 we obtain:

$$
W_{e}=1023 \cdot 10^{9} \times 3.6=3683 \cdot 10^{9} \mathrm{MJ}
$$

Thus, in 2010 the amount of produced petrol $\left(Q_{P}\right)$ was $36 \mathrm{mln}$. tons or $36 \cdot 10^{9} \mathrm{~kg}$. Specific heat of combustion of petrol $\left(H_{P}\right)$ is $41.87 \mathrm{MJ} / \mathrm{kg}$ or $41.87 \cdot 10^{6}$ $\mathrm{J} / \mathrm{kg}$.

The combustion energy of the produced petrol is calculated using the expression:

$$
W_{P}=Q_{P} \times H_{P}
$$

For initial data on the produced petrol for the year 2010 we obtain:

$$
W_{P}=36 \cdot 10^{9} \times 41.87 \cdot 10^{6}=1507 \cdot 10^{9} \mathrm{MJ}
$$

The combustion energy of diesel fuel is calculated in a similar way. The amount of diesel fuel $\left(Q_{D}\right)$ produced in 2010 was $69.9 \cdot 10^{9} \mathrm{~kg}$. The specific heat of combustion of diesel fuel $\left(H_{D}\right)$ is $43.5 \cdot 10^{6} \mathrm{~J} / \mathrm{kg}$.

When considering the initial data of 2010, the combustion energy of all diesel fuel will be: 


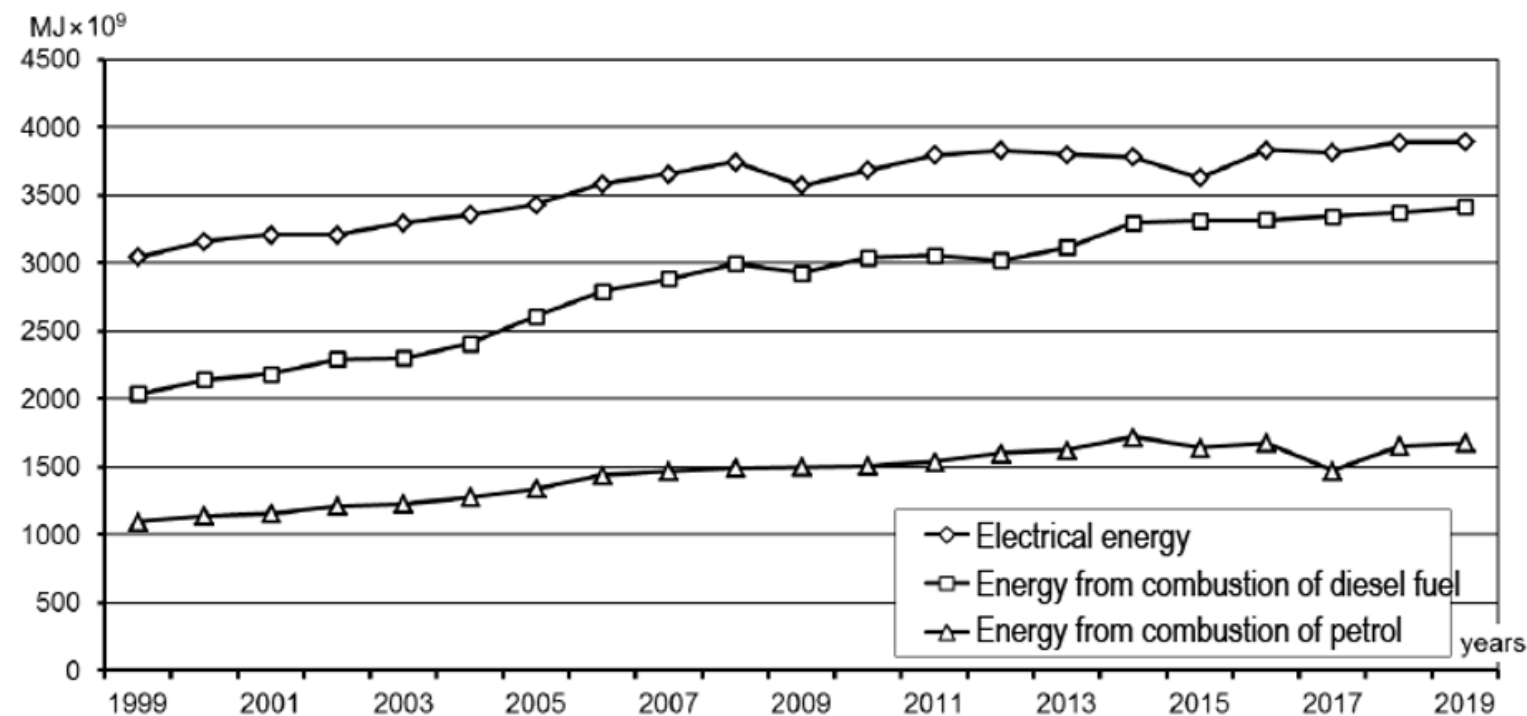

Fig. 3. The dynamics for electrical energy consumed in the Russian Federation, thermal energy from combustion of diesel fuel and petrol over 20 years, reduced to MJ.

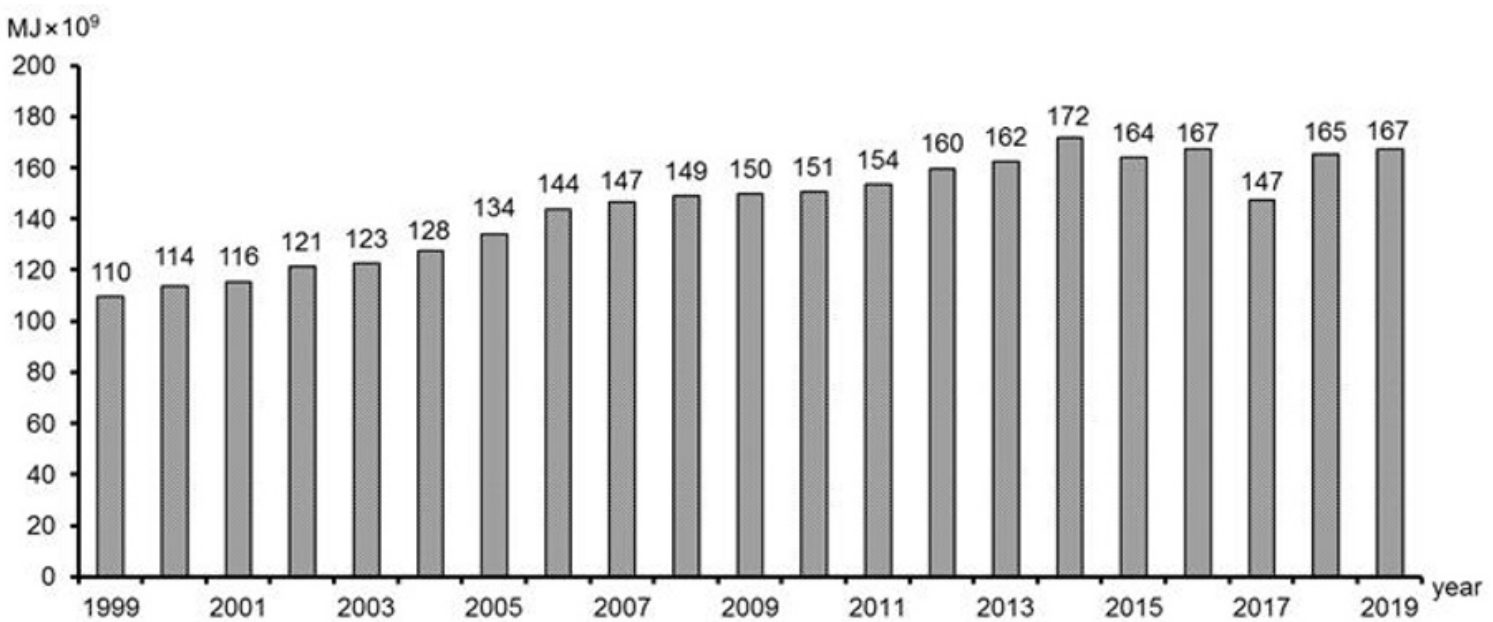

Fig. 4. The dynamics of useful transport work done by petrol cars over the past 20 years.

$$
W_{D}=69.9 \cdot 10^{9} \times 43.5 \cdot 10^{6}=3041 \cdot 10^{9} \mathrm{MJ}
$$

Figure 3 presents comparison between the overall produced electrical energy and the energy of the produced petrol and diesel fuel in MJ. In uniform terms, it becomes clear that, on average, the energy of combustion of all produced petrol is about 3 times less than the overall produced electrical energy. But the energy of the produced diesel fuel in recent years is comparable to electrical energy.

However, not all fossil fuel energy is converted into useful work. Most of it is released into the atmosphere in the form of heat. The ratio between the thermal energy of fuel and the energy consumption for the transport process is determined by the operational efficiency of the vehicle [7].

The studies carried out at the Vologda State University [8] and by other scientific groups [9, 10] showed that when a car moves under real operation conditions, the fuel efficiency of internal combustion engine is very low. So in urban operation conditions, the average efficiency of cars with petrol engine approaches $5-6 \%$, and the maximum value, as a rule, does not exceed $20 \%$. Thus, taking the average value of the vehicle's efficiency equal to $10 \%$, we can calculate the useful energy costs.

Energy costs for implementation of useful transport work $W_{U W}$ can be determined by:

$$
W_{U W}=0.1 \cdot W_{i}
$$

For motor vehicles powered by petrol $W_{U W}$ for the year 2010 is:

$$
W_{U W}=0.1 \times 1507 \cdot 10^{9}=151 \cdot 10^{9} \mathrm{MJ}
$$

Based on the performed calculations we constructed a plot of useful work carried out by all petrol vehicles, Figure 4. 


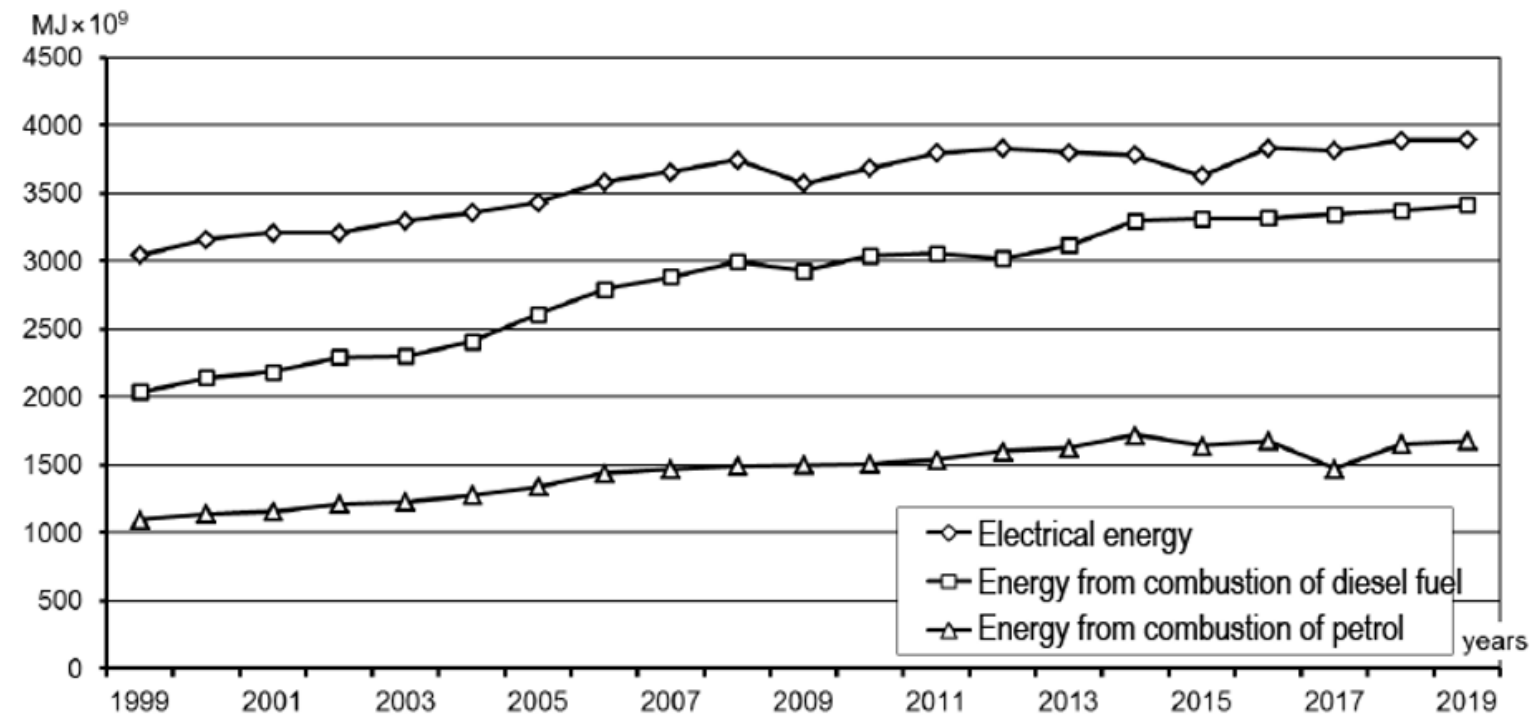

Fig. 5. Additional hypothetical costs of electrical energy in case of replacement of petrol cars in comparison with the amount of electricity produced by all power plants.

Now assume that the amount of transport work shown in figure 4 is performed by electric vehicles, the operational efficiency of which is approximately 0.65 [11-12]. With this in mind, the cost of electrical energy required to charge all electric vehicles is calculated by the formula:

$$
W_{e v}=W_{t r} / 0.65
$$

Figure 5 shows how the total electricity production would correlate with additional hypothetical electricity costs for the charge of all electric vehicles.

Figure 5 shows that the increase in electricity consumption during the theoretical replacement of all petrol cars with electric cars will be about $5 \%$, which should not cause a shortage of electricity in the power system of Russia.

\section{Results}

The presented analysis shows that if all petrol-powered cars are electrified, the load on the existing infrastructure for the production and distribution of electricity will increase by about $5 \%$, which is not significant. Consequently, the wide-sweeping conversion of cars with petrol engine to run on electricity is quite achievable in the coming years. Nevertheless, it should be noted that the growth in electricity consumption can be uneven and will affect, first of all, large cities. Therefore, the infrastructure of charging stations should be developed step by step as far as the volume of electricity generation increases or it is saved through the introduction of energy-efficient technologies.

\section{Conclusions}

The calculations show that the wide-sweeping conversion of cars with petrol engine to run on electricity will not lead to a significant overload of the existing power system and can be carried out in the near future.

Wide-sweeping conversion to electricity of heavy vehicles and buses with diesel engines with the existing power system is impossible for 2 reasons. Firstly, there are no compact, energy-intensive and relatively cheap batteries of electrical energy, which will not lead to a significant loss of carrying capacity. The charging time of existing batteries also does not allow them to be used with significant daily runs. Secondly, the generation of electrical energy of the whole power system should almost double, which can't be achieved in a short time even if not take into account the need to modernize the existing distribution infrastructure.

The use of hybrid power plants in freight and passenger vehicles can become a more acceptable option for large cities. Moreover, it creates the possibility of a systematic development of power supply system with the final transition to electric cars in the future.

The presence of a transitional stage is also justified from an environmental perspective. The accumulated experience in operating vehicles with a hybrid engine shows that they have much higher environmental performance than conventional cars with internal combustion engines. In addition, with a limited daily mileage typical for operation in city, the use of plug-in hybrid vehicles is allowed, which further reduces the need for hydrocarbon fuel. 


\section{References}

[1] D.I. Demidov, V.V. Pugachev, Forecast of global development of electric transport and infrastructure of electric charging stations [Prognoz global'nogo razvitiya elektrotransporta i infrastruktury elektricheskikh zapravochnykh stantsiy], News of the Orenburg State Agrarian University 5, 79, 173-178 (2019).

[2] V.E. Yutt, B.K. Ospanbekov, Promising directions for the development of charging stations for electric vehicles [Perspektivnyye napravleniya razvitiya zaryadnykh stantsiy dlya elektromobiley], Electronics and electrical equipment of transport 6, 10-12 (2013).

[3] D.Yu. Tsypulev, Influence of development of electric transport on power systems [Vliyaniye razvitiya elektrotransporta na energeticheskiye sistemy], Energy policy 1, 58-65 (2012).

[4] D.Yu. Tsypulev, Electric transport and its integration in intellectual networks of the future [Elektrotransport $\mathrm{i}$ ego integratsiya $\mathrm{v}$ intellektual'nyye seti budushchego], Alternative fuel vehicles 1, 31, 24-28.

[5] J. Dong, L. Changzheng, L. Zhenhong, Charging infrastructure planning for promoting battery electric vehicles: An activity-based approach using multiday travel data, Transportation Research Part C: Emerging Technologies 38, 44-55 (2014). DOI: 10.1016/j.trc.2013.11.001.

[6] I.K. Aleksandrov, V.A. Rakov, Analysis of prospects for the development of electrified road transport [Analiz perspektiv razvitiya ehlektrificirovannogo avtomobil'nogo transporta], Transport of the Russian Federation 2, 50-52 (2012).

[7] I.K. Aleksandrov, O.L. Belkov, V.A. Rakov, Assessment of the energy efficiency of ICE in unsteady mode [Otsenka energeticheskoy effektivnosti DVS v usloviyakh neustanovivshegosya rezhima raboty], Engineering Bulletin 6, 17-20 (2008).

[8] I.K. Aleksandrov, E.V. Nesgovorov, V.A. Rakov, Tractional Calculations for Vehicles with Adaptive Motors, Russian Engineering Research 30, 2, 122-124 (2010). DOI: 10.3103/S1068798X1002005X.

[9] V. Rakov, V.N. Ivanov, Y.G. Karpov, V.F. Melehin, R.A. Izmailov, V.K. Yun, D.A. Zaripova, Method for determining the basic energy characteristics of elements of a hybrid car engine, IOP Conference Series: Earth and Environmental Science 337, 1 (2019). DOI: $10.1088 / 1755-1315 / 337 / 1 / 012066$.

[10] I.K. Aleksandrov, Energy efficiency of machine with partial energy recovery [Energeticheskiy KPD mashiny s chastichnoy rekuperatsiyey energii], Engineering Bulletin 9, 17-18 (2007).

[11] I.K. Aleksandrov, Determination of hybrid power installation parameters based on trolleybus driving cycle studies [Opredeleniye parametrov gibridnoy silovoy ustanovki na osnovanii issledovaniy yezdovogo tsikla trolleybusa], Alternative fuel vehicles 5, 41, 54-60 (2014).

[12] G. Pistoia, Electric and hybrid vehicles, Power sources, models, sustainability, infrastructure and the market (Oxford: The Netherlands Linacre House, Great Britain, 670, 2010). 